The Federal Government and Slavery: Following the Money Trail

David F. Ericson

This study contributes to two bodies of literature. First, it amends the recent literature on the development of the American state. ${ }^{1}$ Second, it amends the recent literature on the impact of slavery on American public policy. In fact, this study uniquely brings together those two bodies of literature by showing how slavery contributed to the development of the American state. While the first body of literature largely ignores how slavery affected the development of the American state, the second traces the proslavery biases of federal policies without discussing how those policies positively affected the development of the American state. The assumption common to both bodies of literature is that to the extent slavery affected the development of the American state it negatively affected that development. ${ }^{2}$ This study corrects that assumption.

Stephen Skowronek's analysis of the development of the administrative capacity of the American state during the Progressive era has powerfully influenced the field of American political development. Skowronek argued that the Progressive era was the "critical juncture" when an early American state of "courts and parties" was transformed into a more modern bureaucratic state. Though at times he characterized the early American state as relatively weak and stateless compared to the twentieth-century American state, he ultimately concluded that they were two different kinds of states. ${ }^{3}$

For the most part, Richard Bensel agreed with Skowronek’s assessment of the early American state. ${ }^{4}$ But unlike Skowronek, Bensel analyzed the massive state-building programs that were launched during the Civil War, in both the North and the South. He, however, viewed the emergence of a strong American state--actually two strong American states-during the Civil 
War as a false development. By the end of Reconstruction, most of the Civil War state-building programs had been abandoned. Also unlike Skowronek, Bensel identified slavery as one of the factors that weakened the early American state insofar as the institution fostered anti-statist attitudes among Southern congressmen. With the return of the Confederate states to the union, Southern anti-statism re-emerged as one of the factors that fueled a post-Reconstruction retrenchment. $^{5}$

Karen Orren was a third major scholar who argued that the early American state and the twentieth-century American state were qualitatively different states. Orren, though, distinguished the two states on a feudal-liberal dimension, radically extending the sense in which the early American state was "early." She also stressed the unevenness of the transition between the two states, with some institutions ordered differently than others at any point in that transition. ${ }^{6}$ In two later articles, Orren explained how the institutions of the early American state were organized around the feudal protection of officeholders' rights more than the liberal

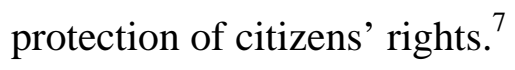

Finally, Theda Skocpol analyzed the Civil War military pension programs and the "maternalist" social policies of the Progressive era as early examples of social welfare spending in the United States. ${ }^{8}$ On the dimension of social welfare spending, she thus suggested a "fits and starts” transition between the early American state and the modern American state. Nonetheless, Skocpol agreed with Skowronek's characterization of the early American state as a state of “courts and parties” and with Bensel's claim that the massive state-building programs that were launched during the Civil War had few long-term effects ${ }^{9}$

More recently, two scholars have examined the pre-Civil War period more closely and concluded that the early American state was not as stateless as previously supposed. Richard 
John argued that the United States postal service was one area of federal bureaucratization during the pre-Civil War period. ${ }^{10}$ Laura Jensen found the roots of the American welfare state in the pre-Civil War military pension and land grant programs. ${ }^{11}$ Both John and Jensen targeted developments that seemed divorced from slavery. John, however, noted how slavery negatively affected federal state-building programs, not only in the area of the postal service, where the abolitionist mailings controversy led to a devolution of authority, but also in the area of internal improvements. $^{12}$

This theme has been a standard theme in studies that explore how slavery influenced federal policy during the pre-Civil War period. These studies have demonstrated that the federal government was heavily implicated in the continued existence of slavery during this period; so much so that it often seemed to act as the agent of a "slaveholding republic."

Paul Finkelman has catalogued the proslavery biases of federal policies during the initial decades of the pre-Civil War period, from the framing of the Constitution to the 1793 fugitiveslave law and early trans-Appalachian territorial policies. ${ }^{13}$ Robin Einhorn has indicated how slave "property" stymied early congressional attempts to levy direct taxes. ${ }^{14}$ Pamela Baker has chronicled how Southern congressmen blocked internal improvement projects during the Jacksonian era for fear of creating a strong American state that could, and would, take action against slavery. ${ }^{15}$ Don Fehrenbacher has offered the most comprehensive case for the Southern, proslavery slant of federal policies throughout the whole period. ${ }^{16}$ Yet, none of these studies demonstrated how slavery positively affected the development of the American state.

This study fills that void. Slavery was a crucial factor in the development of the early American state. Other factors were also crucial. ${ }^{17}$ The nation's two wars of independence with Great Britain were obviously crucial, as were territorial expansion and the military conflicts and 
removal policies that resulted from that expansion. But slavery has been an under-appreciated factor, especially in view of its contribution to such military conflicts and territorial policies as the Seminole wars and their removals from Florida. ${ }^{18}$

This study shows how slavery was a crucial factor in the development of the early American state by detailing federal expenditures on slavery-related items. ${ }^{19} \mathrm{By}$ "following the money trial," it presents a more complete picture of how exactly slavery contributed to the development of the federal government and of how intimately the two institutions were connected with each other than has been presented in previous studies of the early American state. This approach is necessary because many of the connections between the federal government and slavery occurred off the radar screen of public policy, such as its subsidization of African colonization and routine use of slave labor. ${ }^{20}$

Federal budgetary data from the pre-Civil War period is incomplete and very difficult to access. This study is an exploratory study of federal expenditures on slavery-related items during this period. ${ }^{21}$ The sums I found were a relatively small proportion of the total federal budget over those years. Largely as a result of increased spending on interdicting illegal slave trading, the sums increased over time, to peak in fiscal year 1860-1861 at somewhat less than 2\% of the federal budget. ${ }^{22}$ Any reliable estimate, however, is likely to prove elusive because so much of the spending appears to have been undocumented. An undetermined amount of military spending, which frequently exceeded half the federal budget during the period, was also slaveryrelated. ${ }^{23}$ In any case, the significance of the sums I found transcended their size in disclosing the many ways that the federal government and slavery were entangled with one another at the time. 
Federal expenditures on slavery-related items were also significant in contributing to the development of the early American state. We can gauge this significance by examining the three major areas of slavery-related federal expenditures through the lens of both Bensel's dimensions of state authority and the Orren and Skowronek definition of political development as durable shifts in governing authority. ${ }^{24}$

Bensel noted that central states attempt to control their borders. ${ }^{25}$ Though we do not often think of the slave-trade ban as a form of immigration control, it was. ${ }^{26}$ It simply targeted a different group of people than later immigration control efforts. ${ }^{27}$ Arguably, African slaves were the first group targeted because large numbers of Africans had already been forced to "emigrate" to the United States prior to $1808 .^{28}$ Federal efforts to enforce the ban precipitated several shifts of authority, from the state to the federal level and then internally within the federal government, from the Treasury to the Navy Department in 1823 and from the Navy to the Interior Department in $1861 .^{29}$ Bensel also noted that central states attempt to form joint ventures with private organizations to pursue controversial public purposes. ${ }^{30}$ African colonization was such a joint venture between the federal government and American Colonization Society (ACS). ${ }^{31}$ The policy had similar mixed motives to the slave-trade ban, a policy to which it was closely allied in practice. $^{32}$ In both policy areas, the federal government partially dispersed its authority to the ACS. The federal government increasingly turned to this policy mode during the Progressive Era to pursue controversial public purposes. ${ }^{33}$ Finally, Bensel noted that central states attempt to expand their authority at the expense of other governmental entities. ${ }^{34}$ Federal enforcement of fugitive-slave law represented a substantial commitment on the part of the federal government to enforcing its own laws independently of state and local governments. ${ }^{35}$ Again, we usually associate this policy mode with the twentieth-century American state. Fugitive-slave law was 
the clearest case of a slavery-related shift in authority, from the state to the federal level, but also of an incomplete shift of authority because of continuing public resistance to it. ${ }^{36}$

The point of these parallels between pre-Civil War and post-Civil War federal policies is not that the later policies were casually related to the earlier ones. Any durable shifts of authority associated with slavery did not survive the Civil War. Rather, the point of these policy parallels is that the continued existence of the institution induced the early American state to undertake some of the same state-building activities that other factors-whether industrialization (Skowronek), civil war (Bensel), trade unionism (Orren), or women’s activism (Skocpol)induced later American states to undertake. ${ }^{37}$ As John and Jensen have suggested, the early American state was not merely a state of “courts and parties.”38 This study extends their findings into other policy areas where slavery instigated state development. ${ }^{39}$

In the following, I discuss in more detail federal expenditures on the slave-trade ban, African colonization, and fugitive slaves. I also discuss a “miscellaneous” category of slaveryrelated expenditures on such items as slave labor, federal territories, and treaty payments. Each of these types of expenditures merits its own lengthy discussion but I will forgo those discussions in this exploratory study.

The Slave-Trade Ban

The expenditures of the federal government on interdicting illegal slave trading were its largest slavery-related expenditures. ${ }^{40}$ In looking at federal involvement in this policy area, four dates are important. These dates demarcate periods of very different levels of federal involvement in interdicting illegal slave trading. 
In 1787, the delegates to the Federal Convention finally, after several contentious debates over the matter, agreed to insert a clause in the new Constitution that authorized Congress to ban further slave imports into the United States in 1808 or thereafter. ${ }^{41}$ Presumably, then, the slave trade would remain a matter of exclusive state jurisdiction at least until $1808 .{ }^{42}$ There is no record of any federal expenditures for interdicting illegal slave trading during the 1789-1807 period. $^{43}$

On March 2, 1807, Congress enacted a federal slave-trade ban, effective January 1, 1808, as authorized by the Constitution and without any explicit opposition from Southern congressmen. ${ }^{44}$ However, again, there is no record of Congress appropriating any money to enforce the ban during the next twelve years. The effectiveness of the ban depended on the limited effectiveness of federal custom officials working at various ports of entry in deterring slave smuggling and of United States naval vessels patrolling coastal waters in seizing suspected slave traders.

In the wake of a series of communications to Congress that documented the ineffectiveness of its slave-trade ban, ${ }^{45}$ Congress finally enacted a new law on March 3, 1819 to enforce the ban. For the first time, it appropriated money for that purpose, authorizing President James Monroe to spend $\$ 100,000$ to interdict illegal slave trading. Yet, at least initially, Monroe diverted the money to help the ACS establish a colony for expatriated African Americans on the west coast of Africa. Monroe's pretext was that this colony would eventually become the base of operations for the United States naval force that would interdict illegal slave trading off the African coast as well as serve as the entrep $t$ for any Africans that force seized from slave traders. ${ }^{46}$ This naval force remained a fiction more than a reality for the next quarter century. Federal expenditures for interdicting illegal slave trading remained relatively small. From May 
29, 1819 to November 11, 1828, documented federal expenditures were $\$ 200,153 .{ }^{47}$ Until the African Squadron was established in 1843, federal expenditures for interdicting illegal slave trading probably averaged what they had during the $1819-1828$ period, approximately $\$ 20,000$ per year, for a $1819-1842$ total of $\$ 480,000 .^{48}$ Without any permanent naval force devoted to interdicting illegal slave trading, federal expenditures in this policy area were as insignificant as the actual interdiction of slave traders was. ${ }^{49}$

The Webster-Ashburton Treaty of 1842 led to an exponential increase in federal expenditures for interdicting illegal slave trading. The treaty negotiated a number of grievances between the United States and Great Britain. Two grievances were directly related to the slave trade. First, the British government had long complained to the United States government that it was not enforcing its slave-trade ban and, in fact, was seriously complicating Great Britain’s own efforts to interdict illegal slave trading by allowing its flag to be abused by slave traders seeking to escape British interdiction. Second, the United States government had long complained to the British government that its naval vessels were illegally searching and seizing American ships as suspected slave traders. ${ }^{50}$ The agreement of the United States government to finally establish its own permanent African Squadron, as contemplated in the 1819 law and as Great Britain had done as early as 1816, seemed the best way to arbitrate these two grievances. The squadron resulted in a sizable increase in federal expenditures on interdicting illegal slave trading: $\$ 2,691,000$ from 1843 to $1850 ;{ }^{51}$ an estimated $\$ 5,309,000$ from 1851 to 1861 ; and an estimated total of $\$ 8,000,000$ for the $1843-1861$ period. $^{52}$ The amount of money spent on interdicting illegal slave trading during this period was not insignificant. At estimated expenses of $\$ 834,000$ in fiscal year 1860-1861, it would have represented $1.3 \%$ of a total federal budget of $\$ 66,547,000 .^{53}$ 
The federal government could and should have done more to interdict illegal slave trading during the whole 1789-1861 period. In assessing how much it did do, it is a case of whether we look at the glass as half full or half empty. ${ }^{54}$ The contemporary significance of the case probably lay more in the amount of money the federal government did not spend to interdict illegal slave trading than in how much it did spend. At least compared to how much the British government spent, the American amounts were paltry. British expenditures on interdicting illegal slave trading from 1816 to 1861 may have exceeded fifty-seven billion dollars. ${ }^{55}$

From one perspective, the continued existence of slavery in the United States during the pre-Civil War period depressed federal spending in this policy area because it weakened the resolve of American officials to interdict illegal slave trading relative to their British counterparts. ${ }^{56}$ However, from another perspective, federal spending in this policy area would have been even less if the institution had not continued to exist during the period because otherwise American officials might have engaged in even less of the enforcement activities of their British counterparts. ${ }^{57}$

But regardless of how we assess the efforts of the federal government in this policy area, we should not lose sight of the significance of the case for American political development. Over time, federal efforts to enforce the slave-trade ban became a state-building activity. Those efforts resulted in increasingly expensive attempts to control the nation's borders and the activities of United States citizens. They expanded the number, compensation, and authority of an assortment of federal employees, including custom officials, United States attorneys and marshals, and Navy personnel. ${ }^{58}$ According to Fehrenbacher, their combined efforts were at least as successful as the immigration control efforts of the more bureaucratic twentieth-century American state. $^{59}$ 


\section{African Colonization}

As we have seen, President Monroe initially diverted congressional appropriations to enforce the slave-trade ban to help the ACS establish a colony for expatriated African Americans on the west coast of Africa. ${ }^{60}$ But by the mid-1820s, this financial arrangement had become victim to growing Southern congressional opposition to the society because of its perceived “softness” on slavery. ${ }^{61}$ Bills to indirectly subsidize the ACS and its colonization efforts were repeatedly introduced in Congress and defeated in the late 1820s and early 1830s, though on one occasion it required a veto from President Andrew Jackson to do so. ${ }^{62}$ The federal government, however, continued to partially pay the salary of a combined federal/ACS agent in Liberia as well as provide the colony with supplies and naval protection during this period. ${ }^{63}$ It also sporadically reimbursed the society, colony, and later nation for the transportation and care of Africans seized from slave traders until the end of the Civil War. ${ }^{64}$

The ACS annual reports and official government documents only partially reveal the extent of the society’s federal financial support. ${ }^{65}$ In 1823, the Treasury Department reported that $\$ 80,431$ of the initial $\$ 100,000$ appropriated for enforcing the slave-trade ban had been spent, though it is unclear whether that entire amount was spent on African colonization. ${ }^{66}$ In 1827, the Secretary of Navy estimated total federal expenditures of $\$ 27,211$ for materials and labor in constructing fortifications in Liberia. ${ }^{67}$ The tenth annual report of the ACS recorded a $\$ 3,000$ payment from the Department of Navy for the transportation and care of a group of recaptured Africans. ${ }^{68}$ The seventeenth annual report of the ACS noted that the federal government had spent \$1,600 per year from 1820 to 1833 on the salary of the Liberian agent. ${ }^{69}$ 
In 1830, a Treasury Department audit uncovered total federal expenditures of $\$ 264,710$ on African colonization for the $1819-1830$ period. $^{70}$

During the next twenty years, the ACS annual reports recorded only two federal payments, totaling $\$ 4,600$, for the transportation and care of recaptured Africans. ${ }^{71}$ In 1847 , the society’s uncompensated costs for the transportation and care of recaptured Africans became a source of official complaint. $^{72}$ The ACS received a much-delayed $\$ 37,800$ federal payment for one group of recaptured Africans in 1851 and another \$200 the following year for two smuggled African children who it had shipped to Liberia. ${ }^{73}$ Finally, in 1858, President James Buchanan decided to formalize this financial arrangement between the federal government and the ACS by recommending to Congress that the society receive \$50 per person for the transportation of recaptured Africans to Liberia and $\$ 100$ per person for the first year of their care there. ${ }^{74}$ In 1860, the ACS transferred authority over the use of the latter funds to the Liberian government. ${ }^{75}$

This new arrangement led to a significant number of transfer payments from the United States government to the ACS and eventually Liberian government, though the exact amount is, again, unclear. ${ }^{76}$ As reported in its annual budgets, total federal payments to the ACS from 1858 to 1861 were $\$ 222,704 .^{77}$ But the federal government continued to make payments to the society throughout the Civil War until a final payment of $\$ 6,963$ in $1865 .^{78}$

Based on the above figures, federal financial support of African colonization for the 1819-1861 period totaled $\$ 545,814 .^{79}$ This figure, though, almost certainly underestimates the total because of the incompleteness of the documentary records.

In any case, the significance of federal funding of African colonization transcended the amount of money spent. It was an early case of two state-building activities that became increasingly prominent after the Civil War: overseas colonization and public subsidization of 
private organizations, which allowed the federal government to accomplish "unofficially" such controversial purposes as overseas colonization. The relationship between the federal government and ACS was surprisingly durable. Despite its intermittent nature and the strong opposition it faced in Congress, the relationship endured from 1819 to 1865 . During that time, a series of Democratic, Whig, and Republican presidents lent the ACS sufficient federal authority and state capacities to enable the society to colonize Liberia and maintain it as an unofficial American colony (even after independence). ${ }^{80}$

African colonization was also a fairly obvious case where the continued existence of slavery in the United States during the pre-Civil War period influenced federal spending patterns. If the institution had not continued to exist during this period, it is unlikely that the federal government would have subsidized the ACS’s Liberian enterprise or that the society would ever

have undertaken such a grandiose project or even existed. ${ }^{81}$ The connection between slavery and federal spending was patently obvious in the case of federal expenditures on the recovery of fugitive slaves.

\section{Fugitive Slaves}

The expenditures of the federal government in helping slaveholders recover their fugitive slaves were probably much smaller, and certainly less aggregated, than its expenditures on interdicting illegal slave trading and African colonization. But they still were significant in tracking how the early American state enforced constitutional rights and developed its own lawenforcement agencies. Four dates are also important in the federal enforcement of the constitutional right of slaveholders to the return of their fugitive slaves. The federal government only became actively involved in enforcing this right after the last date, in the 1850s. 
In 1787, the delegates to the Federal Convention added a fugitive-slave clause to the new Constitution near the end of their proceedings, almost as an afterthought, at the insistence of South Carolina delegate Pierce Butler. ${ }^{82}$ It is unclear how Butler or any other delegate thought the clause would be enforced. However, the fact that Butler's original motion had analogized fugitive slaves to criminals and the placement of the clause in the Constitution immediately following the section on criminal extraditions from one state to another suggest that they thought the process would work the same way in the two cases. ${ }^{83}$ Butler's amended motion that fugitive slaves should not be discharged from labor "in consequence of any regulation subsisting in the state to which they escape" signaled the intent of the clause: to establish a constitutional norm against any free state hindering slaveholders in their efforts to recover their fugitive slaves on the grounds that slavery had no legal existence in the state. ${ }^{84}$ How active state governments should be in helping slaveholders recover their fugitive slaves was apparently an open question in the minds of most of the delegates. ${ }^{85}$ Yet, it is unlikely that they contemplated any active federal role in the process. ${ }^{86}$

On February 12, 1793, Congress enacted a fugitive-slave law that reflected an expansive interpretation of the fugitive-slave clause of the Constitution, but only after both houses of Congress had rejected bills that reflected much more expansive interpretations of the clause. The new law was a response to a political impasse that included both criminal-extradition and fugitive-slave aspects. This impasse occurred when the governor of Virginia refused to honor a request from the governor of Pennsylvania to extradite three Virginians charged with kidnaping James Davis from Pennsylvania and returning him to slavery in Virginia. ${ }^{87}$ After failing to resolve the impasse, President George Washington turned the matter over to Congress for statutory clarification. The resulting law contained sections on both fugitive slaves and criminal 
extraditions. In fact, the initial House bill treated the two cases as identical cases. The bill would have required state and local officials to assist in the recovery of persons fleeing from either justice or slavery on the request of either governors or slaveholders, as the case may be. The bill, however, failed to receive a third reading in the House and legislative activity shifted to the Senate. ${ }^{88}$ The initial Senate bill was similar to the failed House bill. The Senate bill, though, was heavily amended before it was finally approved by the chamber to strip it of any implication that state and local officials had to assist slaveholders in recovering their fugitive slaves. ${ }^{89}$ In its final form, as approved by both houses of Congress, the new law left the recovery process largely in the hands of slaveholders and their agents. The only stipulation was that they had to secure a court-approved certificate of removal before transporting the person they claimed as a fugitive slave from one state to another. The new law then envisioned a largely passive role for both the federal and state governments in the recovery process, which was the supposition of one of the final Senate amendments that added penalties for state and local officials who hindered slaveholders in their efforts to recover their fugitive slaves. The law certainly "leaned South" in favoring the claims of slaveholders over the rights of blacks, whether escaped slaves or not. ${ }^{90}$ Nevertheless, it leaned less South than the original bill and over time slaveholders were to find its “self-help” provisions unsatisfactory.

In Prigg v. Pennsylvania (1842), the Supreme Court provided an expansive interpretation of the 1793 fugitive-slave law and its expansive interpretation of the fugitive-slave clause of the Constitution, though at least one justice argued for a much more expansive interpretation. The circumstances of the case were similar to those surrounding the 1793 law. Edward Prigg was convicted of violating Pennsylvania’s anti-kidnaping law after he seized Margarette Morgan and her children and attempted to return them to slavery in Maryland. ${ }^{91}$ However, there were no 
extradition aspects to the case because Prigg had been extradited by the governor of Maryland in order to test the constitutionality of the Pennsylvania law. On appeal, the Supreme Court overturned Prigg's conviction as well as the Pennsylvania law on the grounds that it infringed on an area of exclusive federal jurisdiction. But the court also ruled that state and local officials were not obligated to help slaveholders recover their fugitive slaves nor could federal officials compel them to do so. ${ }^{92}$ The decision thus established the supremacy of federal over state law but not of federal over state officials. In principle, the decision should not have materially affected the fugitive slave recovery process since the 1793 law had placed that responsibility in the hands of the slaveholders themselves, not in the hands of either federal or state officials. Yet, in practice, the decision had a dramatic impact on the recovery process. This impact arose from the fact that the "self-help" provisions of the 1793 law were only as effective as the ability of slaveholders to find a legal apparatus, either on the federal or state level, that was at least not unfriendly to the recovery process. Northern state legislatures interpreted the Prigg decision as an invitation to establish unfriendly legal apparatuses. ${ }^{93}$ In reaction, Southern slaveholding elites pressed Congress to establish a stronger, more friendly federal legal apparatus to assist in the recovery process and counteract the increasingly unfriendly state apparatuses. Prigg seemed to invite this step as well. ${ }^{94}$

The fugitive-slave law of 1850 created this stronger, more friendly federal legal apparatus for Southern slaveholders and, by the way, completed the process of severing fugitive-slave cases from criminal-extradition cases. The new law provided for court-appointed United States commissioners to grant certificates of removal in fugitive-slave cases, authorized United States marshals to appoint deputies and organize posses to secure the return of fugitive slaves in the face of local resistence, and obligated the federal government to pay the costs for the protection 
and transportation of fugitive slaves in cases where such resistence was anticipated. ${ }^{95}$ Of course, the new apparatus was only as strong as the will of federal officials to use it. The law had been enacted as one of the pro-Southern parts of the Compromise of 1850. Throughout the rest of the decade, both Whig and Democratic administrations were determined to enforce the law to make that compromise a reality. Despite several celebrated slave rescues, the law was enforced. Slaveholders were successful in pressing their claims to alleged fugitive slaves in the vast majority of the cases that fell under the law.

In his study of the enforcement of the law, Stanley Campbell found 332 fugitive slave recovery cases during the 1850-1860 period. In these 332 cases, 141 alleged fugitive slaves (42.5\%) were reclaimed without any federal court proceedings; meaning that they were essentially kidnaped by slaveholders or their agents. The remaining 191 cases involved federal court proceedings. In these 191 cases, 157 alleged fugitive slaves were remanded to their claimants (82.8\%), 11 were released (5.8\%), 22 were rescued (11.5\%), and 1 escaped (0.5\%). In 68 of the 157 cases (43.4\%) where alleged fugitive slaves were remanded to their claimants, the federal government paid protection and transportation costs. ${ }^{96}$ In possibly the most expensive of these 68 cases--the Arthur Burns case in Boston (1854)--Campbell calculated federal expenditures of \$14,166 to return Burns to slavery in Virginia. ${ }^{97}$ Treasury Department ledgers recorded protection and transportation costs in 23 other cases, ranging from $\$ 25$ to $\$ 745 .{ }^{98}$ If we add the costs of these 23 cases to the cost of the Burns case, we obtain a sum of $\$ 18,759$ in documented federal expenditures. This figure, however, represents only the tip of the proverbial iceberg. It does not include any costs for the 44 other fugitive-slave cases in Campbell's population that involved federal protection and transportation costs and it includes court costs 
only for the Burns case, not for the 190 other fugitive-slave cases in Campbell's population that involved federal court proceedings. ${ }^{99}$

Total federal expenditures for slave recoveries during the whole 1789-1861 period would also include any federal expenses in fugitive-slave cases that fell outside Campbell’s population. ${ }^{100}$ In addition, the federal government assisted slaveholders in attempting to recover their "lost" slaves in other ways or, alternatively, in securing compensation for slave losses. For example, the federal government paid \$5,465 in prize money to several Navy personnel for the destruction of a fort occupied by runaway slaves in what was then Spanish Florida. ${ }^{101}$ In a later case, Secretary of War John C. Calhoun authorized an \$1,000 payment to an army captain for the recovery of slaves seized by a Creek raiding party along the Georgia-Florida border. ${ }^{102}$ Indian agent William DuVal was paid \$1,285 in extra expenses to arbitrate slave disputes between Seminoles and white settlers in territorial Florida. ${ }^{103}$ The federal government also assisted slaveholders in attempting to secure compensation for their slaves in cases where they were “liberated” by foreign powers, such as by Great Britain during the Revolutionary War and War of 1812. This type of support of slavery carried significant costs to the federal government in negotiating, litigating, and processing these cases. The cost to the federal government of the two commissions that were established to settle War of 1812 claims for slave losses was $\$ 56,887 .{ }^{104}$ The federal government itself ultimately paid $\$ 35,880$ to settle one Revolutionary War claim. ${ }^{105}$ Total federal expenditures for slave recoveries during the 1789-1861 period must have dwarfed the spending on fugitive-slave cases. The sum for the five items documented above is $\$ 100,517$.

The significance of federal spending in this policy area, though, transcended the amount of money spent. However modest the expenditures may have been, they suggest important parallels between pre-Civil War and post-Civil War state-building activities in the United States. 
In order to implement fugitive-slave law, the federal government created a separate lawenforcement apparatus and used it to enforce the constitutional rights of individual slaveholders. After the Civil War, the federal government greatly expanded its efforts on both fronts, both in creating its own law-enforcement apparatuses and in enforcing the constitutional rights of individual citizens. At least initially, the constitutional rights it enforced were those of the very people who had been the targets of its pre-Civil War efforts. ${ }^{106}$ Obviously, the pre-Civil War federal expenditures in this policy area were not seen as precedents for the post-Civil War expenditures. Yet, both cases represented federal efforts to bypass resistant state and local governments and directly affect the lives of individual citizens (and noncitizens). In both cases, those efforts were only partially successful.

Federal spending on slave recoveries shows the most unmediated influence of the continued existence of slavery on federal spending patterns during the pre-Civil War period. It also shows how Southern slaveholding elites were not adverse to a powerful federal government. When it directly served their interests, they were as eager to support an extension of federal authority as other Americans were. ${ }^{107}$

\section{Miscellaneous}

Federal spending on interdicting illegal slave trading, subsidizing African colonization, and recovering fugitive slaves did not exhaust the extent of federal spending on slavery-related items during the pre-Civil War period. Though the amounts are hopelessly disaggregated, the federal government spent a sizable amount of money on slave labor. Those expenditures took two forms: payments to federal contractors who used slave labor and payments to slaveholders for the use of their slaves as federal employees. The estimated costs of slave labor to one federal 
subcontractor was $\$ 40,000$ for work on a military fortification near Mobile, Alabama. ${ }^{108}$ The construction of new dry docks at Norfolk, Virginia, cost the Navy an estimated \$119,246 in slave labor. ${ }^{109}$

Federal expenditures in territories could "spike” because of local conflicts over slavery, as clearly occurred in "bleeding” Kansas. The Treasury Department reported that an 1856 congressional investigation of the violence in Kansas cost $\$ 2,400 .{ }^{110}$ Subsequently, President Franklin Pierce asked Congress for $\$ 8,118$ to help defray the extraordinary expenses the Kansas territorial militia incurred in 1856 and the Buchanan administration recommended that it appropriate $\$ 7,003$ to cover the extraordinary expenses Robert J. Walker, the former territorial governor of Kansas, incurred in 1857. ${ }^{111}$ An 1858 special election in Kansas, which led to the ultimate defeat of the Lecompton constitution, cost the federal government $\$ 10,000 .{ }^{112}$ Territorial governors and residents fearful of slave insurrections and the loss of their slaves to Native Americans also frequently petitioned the Department of War to station more troops in their territories. ${ }^{113}$

The federal government incurred treaty obligations because of slavery. The United States paid at least $\$ 18,149$ on claims for slave losses during its 1812-1813 and 1817-1818 military incursions into Spanish Florida under the terms of the Adams-Onís treaty by which it acquired the territory. ${ }^{114}$ The federal government also provided extra sections of land to Chickasaw slaveholders in the treaty by which the Chickasaws ceded their lands in Georgia and Alabama to the United States in exchange for lands in Arkansas territory. ${ }^{115}$

Finally, there were truly miscellaneous federal expenditures on slavery. For example, Secretary of State Calhoun, in a "strictly confidential" letter to the United States ambassador to France, authorized him to spend $\$ 500$ to plant stories in the French press favorable to the South 
and its "peculiar" institutions at the time of the annexation of Texas. ${ }^{116}$ In a related case, President John Tyler admitted paying Duff Green, a Virginia newspaper editor and Calhoun confidante, $\$ 1,000$ out of a contingency fund for his role in promoting the annexation of Texas. ${ }^{117}$ The total amount spent in this miscellaneous category is impossible to estimate. Yet, it is clear that the federal government was involved in many intricate ways in the continued existence of slavery during this whole period and that it spent a considerable amount of money as a result. The $\$ 205,416$ I have documented above is the mere tip of another iceberg.

Specifically with reference to slave labor, the continued existence of slavery expanded the capacities of the federal government in a very concrete way. As federal officials defended the use of slave labor from its critics, it became a simple cost-saving measure that allowed them to complete more projects more cheaply. ${ }^{118}$ The continued existence of slavery also influenced foreign and territorial policy and induced the federal government to extend its authority over both policy areas in ways it might otherwise not have. ${ }^{119}$

\section{Conclusion}

The pre-Civil War budgetary data is incomplete but it is sufficient to support two major conclusions about the relation of slavery to American political development. First, the spending patterns of the federal government would have been significantly different if slavery had not continued to exist in the United States during this period. In some policy areas, the continued existence of the institution did not inhibit federal spending but encouraged it. Second, the continuing existence of slavery prompted the early American state to undertake a number of state-building activities that it might not otherwise have undertaken. Prodded by the sting of slavery or, alternatively, of slaveholders, the early American state engaged in immigration 
control and overseas colonization, subsidized private organizations, and enforced its own laws, all in ways analogous to later American states. ${ }^{120}$ Any causal connections between the pre-Civil War and post-Civil War policies in these areas were, at best, tenuous. Nonetheless, the parallels between the two sets of policies call into question the assumption that slavery had an overall negative impact on the development of the early American state. To the contrary, the federal government made a number of policy commitments because of the continuing presence of slavery on American soil. Over time, those commitments became increasingly expensive ones and spurred such institutional developments as the creation of a separate African Squadron in the Navy, a federal agency in Liberia, and expanded roles for United States commissioners and marshals in the Attorney's General office. They also produced several shifts of authority, from the state to the federal level as well as within the federal government itself. The most durable of those shifts lasted until the Civil War shattered both the early American state and the institution of racial slavery. 


\section{NOTES}

I wish to thank national archivists Walter B. Hill, Jr., and John K. VanDereedt as well as Wichita State University librarian Nan Myers for their assistance in collecting the data for this study. I also wish to thank Robin Einhorn, Desmond King, Robert Mickey, James F. Sheffield, Jr., and the editors of this journal for their comments on earlier versions of the study.

1.For purposes of this study, "the American state" refers to the federal government. I do not consider how slavery contributed to political development on the state level.

2.I mean "positive” and "negative” strictly in a developmental sense.

3.See Stephen Skowronek, Building a New American State: The Expansion of National Administrative Capacities, 1877-1920 (Cambridge, UK: Cambridge University Press, 1982), pp. 3-5, 8, 19-20, 23.

4.See Richard Franklin Bensel, Yankee Leviathan: The Origins of Central State Authority in America, 1859-1877 (Cambridge, UK: Cambridge University Press, 1990), pp. ix, 36, 63, 98.

5.See Bensel, Yankee Leviathan, pp. 2-3, 10, 63, 237. Bensel claimed that the return of Democratic Party competition and fissures within the Republican Party were other factors in this retrenchment.

6.See Karen Orren, Belated Feudalism: Labor, the Law, and Liberal Development in the United States (Cambridge, UK: Cambridge University Press, 1991), pp. 1-4, 8-9, 30-33, 68-71.

7.See Karen Orren, “ ‘A War Between Officers’: The Enforcement of Slavery in the Northern United States, and Of the Republic for Which It Stands, Before the Civil War,” Studies in 
American Political Development 12 (Fall 1998): 343-82; Karen Orren, “Officers’ Rights:

Toward a Unified Field Theory of American Constitutional Development,” Law and Society Review 34, no. 4 (December 2000): 873-909.

8.See Theda Skocpol, Protecting Soldiers and Mothers: The Political Origins of Social Policy in the Untied States (Cambridge, MA: Belknap Press of Harvard University Press, 1992), pp. vii-ix, 1-3, 8-10, 43-45. Skocpol’s “puzzle” was why widows’ pension programs, for example, were enacted in the United States before comparable programs for men.

9.See Skocpol, Protecting Mothers, pp. 66-76.

10.See Richard R. John, Spreading the News: The American Postal System from Franklin to Morse (Cambridge, MA: Harvard University Press, 1995), pp. 4-6, 18-20, 300 (n. 2).

11.See Laura Jensen, Patriots, Settlers, and the Origins of American Social Policy (Cambridge, UK: Cambridge University Press, 2003), pp. 5-10, 40-43, 120-22, 227-28.

12.See John, Spreading the News, pp. 207-08, 256, 270-71, 280.

13.See Paul Finkelman, Slavery and the Founders: Race and Liberty in the Age of Jefferson (Armonk, NY: M. E. Sharpe, 1996).

14.See Robin L. Einhorn, "Slavery and the Politics of Taxation in the Early United States," Studies in American Political Development 14 (Fall 2000): 156-83. 
15.See Pamela L. Baker, “The Washington National Road Bill and the Struggle to Adopt a Federal System of Internal Improvement,” Journal of the Early Republic 22, no. 3 (Fall 2002): $437-64$.

16.See Don E. Fehrenbacher, The Slaveholding Republic: An Account of the United States Government’s Relations to Slavery (New York: Oxford University Press, 2001).

17.Slavery might also have depressed federal growth in certain policy areas, as Einhorn and Baker have argued with respect to tax policy and internal improvements. See Einhorn, "Politics of Taxation,” p. 157; Baker, “Washington Road,” p. 439. In both cases, though, there were other reasons why the federal government did not use its authority to a greater extent, such as a general antipathy toward direct taxation and "big government" that extended well beyond the slaveholding class. We should also recall that cotton and other slave-produced exports were largely responsible for the nation's economic growth during this period. See Douglas C. North, The Economic Growth of the United States, 1790-1860 (Englewood Cliffs, NJ: Prentice-Hall, 1961). The federal government might then have had less, rather than more, revenue if slavery had not continued to exist at the time. Yet, the relationship between slavery and federal revenues was an indirect one. By providing the nation's major exports that funded the imports from which the federal government derived its tariff revenues, slavery indirectly provided the federal government with its largest source of revenue. There were alternative paths of development. The federal government could have substituted other revenue sources for tariffs. Staple producers could have substituted free labor for slave labor. Americans could have developed other export products. In any case, the focus of this study is what the federal government chose to do with the money it raised rather than the choices it made in raising that money. 
18.At least in the southeastern United States, the Indian wars and removals were slavery-related in the sense that the five Native-American nations in the area-the Cherokees, Chickasaws, Choctaws, Creeks, and Seminoles--stood in the way of the expansion of slavery; that is, the European-American institution since each of those nations also practiced slavery. The connection was closest in the case of the Seminoles given the large presence of blacks (free, enslaved, and fugitive) among them. John Mahon estimated the expenses of the seven-year-long second Seminole War at between thirty and forty million dollars. See John K. Mahon, History of the Second Seminole War, 1835-1842 (Gainesville: University of Florida Press, 1967), p. 326. See also Fehrenbacher, Slaveholding Republic, pp. 100-01; Kenneth W. Porter, The Black Seminoles: History of a Freedom-Seeking People (Gainesville: University Press of Florida, 1996), pp. 106-07; J. Leitch Wright, Creeks and Seminoles: The Destruction and Regeneration of the Muscogulge People (Lincoln: University of Nebraska Press, 1986), p. 275. A similar, though more ambiguous, connection existed in the case of the annexation of Texas and Mexican War. See Randolph B. Campbell, An Empire for Slavery: The Peculiar Institution in Texas, 1821-1865 (Baton Rouge: Louisiana State University Press, 1989), pp. 29, 35-36, 48-49; Fehrenbacher, Slaveholding Republic, pp. 118-26; Frederick Merk, Slavery and the Annexation of Texas (New York: Knopf, 1972). Other motives were involved in each of these cases. Native Americans were killed and removed fairly indiscriminately across the United States. See Michael Paul Rogin, Fathers and Children: Andrew Jackson and the Subjugation of the American Indian (New York: Knopf, 1975). The annexation of Texas and Mexican War were at least as much partisan issues as they were sectional ones. See Michael A. Morrison, "Martin Van Buren, the Democracy, and the Partisan Politics of Texas Annexation,” Journal of Southern 
History 61, no. 4 (November 1995): 695-724. Whether a particular case was slavery-related or not will always be problematic because of the multicausality of historical events.

19.Slavery-related expenditures were expenditures that would not have occurred if slavery had not continued to exist in the United States at the time. As noted above, this determination will always be problematic but clearly some expenditures (as on fugitive-slave renditions) were less ambiguously related to slavery than others (as on the Mexican War).

20.For example, Fehrenbacher’s otherwise comprehensive Slaveholding Republic does not mention the federal government's use of slave labor and only briefly discusses its support of African colonization.

21.To be exact, this study examines federal expenditures from the convening of the first Congress under the Constitution (March 1789) to the beginning of the Civil War (July 1861).

22.The federal government's fiscal year was the calender year until 1843. Unless otherwise indicated, I have reported budgetary data in calender years or series of calender years.

23.The combined Navy and army budgets exceeded half of the federal budget in 32 of the 73 years from 1789 to 1861. See Historical Statistics of the United States: Colonial Times to 1957 (Washington: U.S. Census Bureau, 1960), pp. 718-19.

24.Bensel conveniently provides a chart on page 114 of Yankee Leviathan showing the policy areas that fall under each dimension. The Orren and Skowronek definition of political development is from: Karen Orren and Stephen Skowronek, The Search for American Political Development (Cambridge, UK: Cambridge University Press, 2004), pp. 123-24. 
25.Immigration control falls under Bensel's “the central state in the world system” dimension.

26.See Aaron S. Fogleman, “From Slaves, Convicts, and Servants to Free Persons: The Transformation of Immigration in the Era of the American Revolution,” Journal of American History 85, no. 1 (June 1998): 50.

27.On these later immigration control efforts, see Daniel Tichenor, Dividing Lines: The Politics of Immigration Control (Princeton, NJ: Princeton University Press, 2002).

28.This formulation leaves open the question of motive as to whether the slave-trade ban was blow against slavery or a blow for racial prejudice. Cf. Fehrenbacher, Slaveholding Republic, pp. 41-43; Rogers M. Smith, Civic Ideals: Conflicting Visions of Citizenship in U.S. History (New Haven, CT: Yale University Press, 1997), p. 169.

29.The State Department and Attorney General’s office were also involved in the enforcement of the slave-trade ban, as were local United States attorney and marshal offices. See Warren S. Howard, American Slavers and the Federal Law, 1837-1862 (Westport, CT: Greenwood, 1976; first published in 1963), p. 258. This case is a good example of what Orren and Skowronek mean by institutional intercurrence. See Orren and Skowronek, Political Development, pp. 11314.

30.Such ventures fall under Bensel’s “creation of client groups” dimension.

31.See H.R. Rep. No. 283, $27^{\text {th }}$ Cong., $3^{\text {rd }}$ Sess. (1843), pp. 5-6. This report was published separately as The Report of Mr. Kennedy of Maryland, from the Committee on Commerce of the House of Representatives of the United States, on the African Slave Trade (Freeport, NY: Books 
for Libraries Press, 1971). I will cite it as the Kennedy Report. See also Annual Reports of the American Colonization Society (New York: Negro Universities Press, 1969), XXVI:20 (1843);

XLVI:19 (1863). I will refer to the society by its acronym and its annual reports as: ACS, volume, page, and year.

32.See Kennedy Report, pp. 176, 213, 439-40, 866, 872, 916, 1016-17.

33.See Robert Lieberman and Sean Farhang, "Public and Private in American State Building: The Interstate Commerce Act of 1887” (paper presented at the annual meeting of the Social Science History Association in Baltimore, November 14-16, 2003).

34.The creation of separate federal law-enforcement agencies falls under Bensel's “centralization of authority” dimension.

35.See Stanley W. Campbell, The Slave Catchers: Enforcement of the Fugitive Slave Law, 18501860 (Chapel Hill: University of North Carolina Press, 1968), pp. vii-viii, 147, 185-86.

36.See Thomas D. Morris, Free Men All: The Personal Liberty Laws of the North, 1780-1861 (Baltimore: Johns Hopkins University Press, 1974).

37.See Skowronek, New American State, p. 35; Bensel, Yankee Leviathan, p. 2; Orren, Belated Feudalism, pp. 3-4; Skocpol, Protecting Mothers, pp. 51-52. Given the recent scholarship, we should probably distinguish more than two American states. Bensel, for example, identified five American states in the 1850 -1900 period: a weak antebellum state; two strong Civil War states; a highly centralized Reconstruction state; and a market-oriented Gilded Age state. See Bensel, Yankee Leviathan, p. 17. 
38.See John, Spreading the News; pp. 4-6, 18; Jensen, Patriots and Settlers, pp. 5-7, 10-11, 91.

39.Again, this study serves as a corrective to, not an overhaul of, the existing American political development literature.

40.The term “interdicting illegal slave trading” covers both slave smuggling into the United States and American participation in slave trading to and from other countries. Fehrenbacher criticized W. E. B. DuBois's classic study of the slave trade for not distinguishing these two activities in arguing that the federal government did not enforce its own slave-trade ban. According to Fehrenbacher, it did, with respect to slave smuggling. Cf. W. E. DuBois, The Suppression of the African Slave-Trade to the United States of America, 1638-1870 (New York: Social Science Press, 1954; first published in 1896), pp. 109-10, 129-30, 182-83; Fehrenbacher, Slaveholding Republic, pp. 149-50, 201-02, 385 (n. 67).

41.The division in the convention on slave imports was as much an upper-lower South division as it was a North-South divison. Virginia and Maryland delegates were conspicuous in advocating a federal ban on such imports and Georgia and South Carolina delegates in opposing one. On this debate, see Finkelman, Founders and Slavery, pp. 19-29.

42.Twelve of the thirteen states had taken some action against the slave trade by 1787 , either prohibiting further slave imports (eleven states) or taxing them (North Carolina). Only Georgia had taken no action against the slave trade by the time of the convention. Then, during the 17891807 period, North Carolina (1794) and Georgia (1798) banned the trade while South Carolina rescinded its ban in 1803. See Jed Handelsman Shugerman, "The Louisiana Purchase and South Carolina's Reopening of the Slave Trade in 1803,” Journal of the Early Republic 22, no. 2 
(Summer 2002): 263-90. In the convention, Georgia and South Carolina delegates predicted that their states would soon (permanently?) ban the trade but this prediction did not prevent them from vigorously opposing any federal authority over it. See Max Farrand, The Records of the Federal Convention of 1787 (New Haven, CT: Yale University Press, 1937; first published in 1911), II:364-65, 371-72.

43.Federal money could have been spent enforcing federal laws against American participation in the slave trade. See Kennedy Report, pp. 298-99.

44.Sectional disputes occurred over the details of the ban, such as whether Africans seized from slave traders should be sold as slaves or freed. Congress compromised on leaving the matter to the discretion of the states where the Africans were seized or transported. See Matthew E. Mason, "Slavery Overshadowed: Congress Debates Prohibiting the Atlantic Slave Trade to the United States, 1806-1807,” Journal of the Early Republic 20, no. 1 (Spring 2000): 64-68.

45.See H.R. Doc. No. $84,15^{\text {th }}$ Cong., $2^{\text {nd }}$ Sess. (1819); H.R. Doc. No. $100,15^{\text {th }}$ Cong., $2^{\text {nd }}$ Sess. (1819); H.R. Doc. No. $107,15^{\text {th }}$ Cong., $2^{\text {nd }}$ Sess. (1819). See also ACS III:53-60 (1820); Kennedy Report, pp. 241-47, 249-56.

46.See H.R. Doc. No. $11,16^{\text {th }}$ Cong., $1^{\text {st }}$ Sess. (1819). Whether Monroe's actions actually constituted a diversion of funds is open to debate since the law was intended to promote the cause of African colonization, as in mandating that Africans seized from slave traders should now be re-settled in Africa instead of the United States. Congress, however, did not explicitly authorize federal funding of African colonization until 1860. See ACS XLIV:10-11 (1861). 
47.See “Expense Annually Incurred under the Act for Prohibiting the Slave Trade,” December 6, 1827, American State Papers: Naval Affairs III:340; “Annual Report of the Secretary of the Navy, showing the condition of the Navy in the year 1828," December 2, 1828, American State Papers Naval Affairs III:370. All figures are rounded to the nearest dollar unless otherwise indicated.

48.Dubois’s estimate for this period was \$333,000. See DuBois, African Slave-Trade, p. 122. He, however, based his estimate on congressional appropriations, not on executive reports. Unfortunately, I found no such reports for the 1829-1842 period but projecting the 1819-1828 costs forward probably provides a more accurate estimate than congressional appropriations, both because the latter were not always spent and also because they did not include indirect costs.

49.After a brief flurry of activity associated with the new law, the United States Navy interdicted only one slave ship off the African coast from 1822 to 1842. See Fehrenbacher, Slaveholding Republic, pp. 154-56.

50.See Kennedy Report, pp. 478-729.

51.See H.R. Ex. Doc. No. 73, $31^{\text {st }}$ Cong., $1^{\text {st }}$ Sess. (1850).

52. These figures are rounded to the nearest thousand dollars. I derived the 1851-1861 estimate from the Secretary of Navy’s $\$ 384,000$ estimate for fiscal year 1850-51 and the assumption that federal spending for interdicting illegal slave trading showed no growth until fiscal year 18581859, when the Buchanan administration significantly increased its commitment to the policy in 
response to reports of widespread American participation in the Cuban slave trade. See $S$. Ex. Doc. No. 40, $31^{\text {st }}$ Cong., $1^{\text {st }}$ Sess. (1850); H.R. Ex. Doc. No. 7, $36^{\text {th }}$ Cong., $2^{\text {nd }}$ Sess. (1860). For the 1859-1861 period, I then assumed a baseline cost of $\$ 384,000$ per fiscal year for the African Squadron plus \$185,000 in costs for recaptured Africans in fiscal year 1858-1859 and \$450,000 in each of the next two fiscal years based on the official estimates for those three fiscal years. See H.R. Misc. Doc. No. 96, $36^{\text {th }}$ Cong., $1^{\text {st }}$ Sess. (1860); H.R. Ex. Doc. No. $7,36^{\text {th }}$ Cong., $2^{\text {nd }}$ Sess. (1860); H.R. Ex. Doc. No. 11, 36 ${ }^{\text {th }}$ Cong., $2^{\text {nd }}$ Sess. (1860). The higher $1860-1861$ estimates were, in turn, based on the record number of slave ships (seven) seized with Africans on board $(4,300)$ in 1860. See Howard, American Slavers, pp. 59, 220-22. (The federal government had agreed to pay \$175 for each recaptured African: \$150 in transportation and care to the ACS and \$25 in bounties to Navy personnel.) Finally, I halved the estimated spending on recaptured Africans for 1860-1861 on the basis of two pieces of evidence: (1) a 1863 letter from the Secretary of Interior to Congress indicating that not all the money appropriated for such purposes had been spent; (2) ACS records indicating that the federal government had paid the society much less than it was “owed." See Records of the Office of the Secretary of the Interior Relating to the Suppression of the African Slave Trade and Negro Colonization, 1854-1872 (Washington: National Archives, 1949), Reel 1: Letters Sent September 8, 1858-February 1, 1872, p. 201 (“Letter to Thaddeus Stevens, chair of House Ways and Means Committee,” February 9, 1863); ACS XLIV:48 (1861). DuBois’s estimate for the 1843-1861 period was \$7,629,000; again, slightly lower than my estimate. See DuBois, African Slave-Trade, p. 122

53.See H.R. Ex. Doc. No. 11, 36 ${ }^{\text {th }}$ Cong., $2^{\text {nd }}$ Sess. (1860); Historical Statistics, p. 718. 
54.Cf. Peter Duignan and Clarence Clendenen, The United States and the African Slave Trade, 1619-1862 (Westport, CT: Greenwood Press, 1978; first published in 1963); Howard, American Slavers, pp. 13, 41, 67-68, 206-10.

55.See David Eltis, Economic Growth and the Ending of the Transatlantic Slave Trade (New York: Oxford University Press, 1987), pp. 92-93. (I converted Eltis’s pound estimates into dollar estimates using an exchange rate of five dollars per pound, which was the approximate rate throughout the period.) By comparison, my estimate of total American expenditures for the same 1816 -1861 period is $\$ 8.48$ million.

56.See DuBois, African Slave-Trade, pp. 158-59.

57.See Matthew E. Mason, “The Battle of the Slaveholding Liberators: Great Britain, the United States, and Slavery in the Early Nineteenth Century,” William and Mary Quarterly, 3d series, 59, no. 3 (July 2002): 690-91.

58.More custom officials were needed to prevent slave smuggling; more attorneys were needed to prosecute slave-trade cases; and more money was needed to pay both as well as to pay Navy personnel bounties for recaptured Africans and marshals for their care in cases requiring litigation. See Clarence Edwin Carter (ed.), The Territorial Papers of the United States (Washington: Government Printing Office, 1934-69), XXII:39, n. 28 (Florida/1821); XXIII:587 (Florida/1826); “Foreign Vessels Engaged in Smuggling Through Florida,” January 13, 1821, American State Papers: Foreign Relations V:343; General Records of the Department of the Treasury, Correspondence of the Office of the Secretary of the Treasury, Letters Received from the Navy Department, 1823-1909. National Archives, Record Group 56, Box 1 (letters dated 
9/19/1860-6/22/1861); Office of Naval Records and Library, Subject File: U.S. Navy, 17751901; 0-1910; SG-Illegal Service, including blockage running, piracy, smuggling, and filibustering. National Archives, Record Group 45, Box 622 ("Letter from Department of Navy to Department of Treasury, in response to Senate Resolution of February 25, 1843,” December 11, 1843); Records of the Secretary of the Interior Relating to the Slave Trade, Reel 2 (log of letters sent to Attorney General’s office; dated 2/14/1859-12/31/1859).

59.See Fehrenbacher, Slaveholding Republic, pp. 150, 201.

60.Most of the expenditures on promoting African colonization were included in the expenditures on interdicting illegal slave trading but it is important to attempt to isolate the former because it demonstrates how much the federal government was involved in what was purportedly a private enterprise.

61.See P. J. Staudenraus, The African Colonization Movement, 1816-1865 (New York: Octagon 1980; first published in 1961), pp. 65-66, 169. The ACS tried to appeal to both proslavery and antislavery sentiment. See Kennedy Report, pp. 175, 182, 187-90, 957-58, 1015-16, 1024-25.

62.See Staudenraus, African Colonization, pp. 172, 176-78, 184-87. By the time of Jackson's veto, the ACS had also become a partisan issue. Jackson vetoed a bill sponsored by Henry Clay, the leader of the Whig opposition, which would have permitted states to fund African colonization as one of the three authorized uses of their share of the public land revenues. See John R. Van Atta, “Western Lands the Political Economy of Henry Clay’s American System, 1819-1832,” Journal of the Early Republic 21, no. 4 (Winter 2001): 662-64. Again, as in the case of the slave-trade ban, the geographic division over the society was as much an upper-lower 
South division as it was a North-South division. See Douglas R. Egerton, “Averting a Crisis: The Proslavery Critique of the American Colonization Society,” Civil War History 43 (June 1997): 143. This division was clear from the states that at one time or another financially supported colonization: Connecticut, New Jersey, Pennsylvania, Maryland, Virginia, Kentucky, Indiana, and Missouri. See ACS XL:8 (1857).

63.See ACS IX:50 (1826); X:53 (1827); XI:38 (1828).

64.Liberia declared independence in 1847. But the United States did not formally recognize the nation until 1862; the same year it finally recognized Haiti and agreed to a mutual right of search and seizure treaty with Great Britain. These three foreign-policy issues bore the strong imprint of slavery. See ACS XXXIX:31-33 (1856); Fehrenbacher, Slaveholding Republic, pp. 111-18, 189-90; Tim Matthewson, A Proslavery Foreign Policy: Haitian-American Relations during the Early Republic (Westport, CT: Praeger, 2003); Staudenraus, African Colonization, p. 241.

65.The ACS's financial secretaries usually used a crude debits and credits format for reporting the society's budget in its annual reports. Four early annual reports-the first, second, third, and sixth-contained no budgets and one annual report--the forty-sixth-contained no itemized budget.

66.See Appropriation Ledgers for the Treasury and Other Departments, Vol. 4, Ledger 9 (January 1, 1819-December 31, 1822), pp. 468, 473. National Archives, Record Group 39. 67.See H.R. Doc. No. 193, $20^{\text {th }}$ Cong., $1^{\text {st }}$ Sess. (1828). Navy personnel helped build these fortifications. See ACS VII:26-27 (1824); XI:38 (1828).

68.See ACS X:53 (1827). 
69.See ACS XVII:28 (1834). The ACS paid \$2,400 per year. A Treasury audit indicated that this subsidy continued at least through September 1841. See Office of Naval Records, Box 622 (“Letter from Treasury Department, Fourth Auditor’s Office, in response to Senate Resolution of February 25, 1843,” December 1, 1843).

70.See Kennedy Report, p. 463.

71.See ACS XIX:28 (1835); ACS XX:33 (1836). The Department of Navy reported $\$ 21,000$ in costs for the transportation and care of two groups of recaptured Africans during this period but there is no indication that the ACS received any of this money. See Office of Naval Records, Box 622 (“Letter to Department of Treasury,” December 11, 1843). The federal government donated two shiploads of weapons and supplies to the ACS in the early 1840s. See ACS XXIII:3-4 (1840); XXVII:34 (1844).

72.See ACS XXXI:13-14 (1848).

73.See ACS XXV:35 (1852).

74.See ACS XLII:21 (1859).

75.See ACS XLIV:14 (1861).

76.The ACS's financial secretary contributed to the problem. He added a column for balances due in the 1859 budget; provided no itemized budget for 1862, following a call at the annual meeting for less complicated budget reports; and then returned to the debits and credits format in the 1863 budget. See ACS XLIII:51 (1860); XLVI:49, 52 (1863); XLVII: 18 (1864). 
77.See ACS XLIII:51 (1860); XLIV:50 (1861); XLV:59 (1862). The forty-fourth annual report noted that vouchers totaling $\$ 203,715$ had been submitted to the federal government through 1861. See ACS XLIV:48 (1861). As of January 1864, the society claimed that it was still owed \$99,728. See ACS XLVII:18 (1864).

78.See ACS XLVII:18 (1864); XLVIII:27 (1865); XLIX: 25 (1866).

79.This figure includes the Treasury audit sum of $\$ 264,710$ for $1819-1830$; $\$ 16,000$ on the Liberian agent for 1831-1840; the ACS annual budget sum of $\$ 222,704$ for 1858-1861; and the three interim payments of $\$ 42,400$.

80.See ACS XXXI:10 (1848); XXXIV:69-71 (1851); XXXVII:11-12 (1854); XXXIX:31-33 (1856); Kennedy Report, pp. 6-7.

81.See ACS I:8 (1818); II:11 (1819); IV:29 (1821); X:74-79 (1827); XXVI:6-12 (1841).

82.The clause was subject to hardly any convention debate, perhaps because Congress had recently included a similar clause in the Northwest Ordinance. See Finkelman, Founders and Slavery, p. 179 ( n. 5).

83.See Farrand, Federal Convention, II:443. Charles Pinckney (South Carolina) co-sponsored Butler's original motion. Roger Sherman (Connecticut) objected to the motion because it seemed to grant slave "property" unique extra-territorial status. James Wilson (Pennsylvania) also objected on the grounds that it would be expensive for state governments to enforce.

84.See Farrand, Federal Convention, II:453-54. Butler’s amended motion was approved without objection. By the time of the convention, five Northern states--Pennsylvania, Connecticut, 
Rhode Island, Massachusetts, and New Hampshire-had acted to abolish slavery. See Arthur Zilversmit, The First Emancipation: The Abolition of Slavery in the North (Chicago: University of Chicago Press, 1967), pp. 109-38.

85.Wilson's initial objection, however, assumed that state governments would be active in enforcing the clause.

86.See Finkelman, Founders and Slavery, pp. 101-02.

87.On this policy episode, see Finkelman, Founders and Slavery, pp. 80-104.

88.Finkelman speculated that the bill died in the House because of second thoughts even among Southern congressmen that it was too expansive. See Finkelman, Founders and Slavery, p. 91.

89.These amendments opened a gap between fugitive-slave and criminal-extradition cases.

90.There was no due process for the person claimed as a fugitive slave.

91.The Pennsylvania legislature had enacted a new law in 1826 that explicitly extended some due process protections to blacks claimed as fugitive slaves. See Morris, Free Men, pp. 51-52.

92.Joseph Story wrote the plurality decision in the case. Eight justices agreed to overturn Prigg's conviction but only three concurred with Story's reasoning. In a separate opinion, Chief Justice Roger Taney argued that the Constitution obligated state and local officials to help enforce federal fugitive-slave law. In his dissent, John McLean acknowledged that fugitive-slave law was one of the few areas of law where federal officials could compel state and local officials to perform certain actions. See Prigg v. Pennsylvania 16 Peters 417 (1842) at 439-40, 467-68. 
93.From 1843 to 1848, eight northern states-Ohio, Pennsylvania, New Jersey, Connecticut, Rhode Island, Massachusetts, New Hampshire, and Vermont--enacted or strengthened "personal liberty” laws that provided various legal protections for blacks claimed as fugitive slaves. See Morris, Free Men All, pp. 219-22.

94.The decision also seemed to invite Orren’s “war between officers.” See Orren, “War Between Officers,” p. 359.

95.Other features of the law were: (1) claimant paid commissioner \$10 if fugitive was remanded to him and only \$5 if fugitive was not; (2) court-approved deposition from state of origin attesting to the identity and status of fugitive sufficient evidence for reclamation; (3) fugitive could not testify in court; (4) civil penalties for obstructing the process. See Morris, Free Men All, pp. 145-46. The last three features were similar to the 1793 law.

96.See Campbell, Slave Catchers, p. 207.

97.See Campbell, Slave Catchers, p. 130. This sum included court costs of $\$ 6,872$ and a $\$ 7,294$ reimbursement to the city of Boston to cover its expenses. Campbell noted that previous accounts of the case had estimated costs as high as $\$ 100,000$, presumably because they had included estimates of the indirect costs involved, such as the costs of the federal troops who were deployed to prevent Burns’ rescue.

98.See Appropriation Ledgers, Vol. 10, Ledger 15 (July 1, 1849-June 30, 1854), p. 346; Vol. 11, Ledger 16 (July 1, 1854-June 30, 1859), p. 561; Vol. 12, Ledger 17 (August 1, 1859-June 30, 
1864), p. 802. Campbell provided federal costs in only two other cases. See Campbell, Slave Catchers, pp. 115 ( n. 5), 117 ( n. 11).

99.In his study of the Margaret Garner case in Cincinnati (1856), Julius Yanuck estimated total costs at between \$30,000 and \$40,000. See Julius Yanuck, “The Garner Fugitive Slave Case,” Mississippi Valley Historical Review 40, no. 1 (June 1953): 63, n. 74. Leonard Levy estimated total costs of \$20,000 for the Thomas Sims case in Boston (1851). See Leonard W. Levy, “Sims' Case: The Fugitive Slave Law in Boston in 1851,” The Journal of Negro History 35, no. 1 (January 1950): 72. But it is not clear what costs these estimates included.

100.Campbell acknowledged that his population of fugitive-slave cases was undoubtedly only a fraction of the whole. See Campbell, Slave Catchers, pp. 112-13. It certainly did not include cases where slaveholders did not even try to recover their fugitive slaves because of the expected futility of the attempt. Cf. Gary Collison, “ ‘This Flagitious Offense’: Daniel Webster and the Shadrach Rescue Cases, 1851-1852,” New England Quarterly 48, no. 4 (December 1995): 624 (n. 42).

101.See 6 Statutes At Large 778 (March 3, 1839). The fort had been destroyed in 1816; a prelude to the first Seminole war. See James W. Covington, “The Negro Fort,” Gulf Coast Historical Review 5, no. 2 (June 1990): 79-91.

102.See Clyde N. Wilson (ed.), The Papers of John C. Calhoun. (Columbia: University of South Carolina Press, 1959-2003), VI:398 (1821). Ironically, Creeks were allied with the United States in its campaigns against the Seminoles and paid as much as $\$ 50$ per slave to capture suspected fugitive slaves among them. See Porter, Black Seminoles, p. 17; Wright, Creeks and Seminoles, 
p. 280. Calhoun's papers also contain a reference to a case where the federal government paid a Native-American woman $\$ 685$ for the loss of a slave stolen from her by a white settler in Florida. See Calhoun Papers, IX:591 (1825).

103.See Carter, Territorial Papers, XXIV:718 (Florida/1832). See also Carter, Territorial Papers, XXIV:8, n. 21 (Florida/1828); XXV:34 (Florida/1834); XXXVI:295 (Florida/1841). 104.See John Bassett Moore, History and Digest of the International Arbitrations to which the United States Has Been a Party (Washington: Government Printing Office, 1898), I:367 (n. 1). The British government refused to pay any claims for slave losses after either war but in the case of the War of 1812 claims it finally agreed to submit the matter to Tsar Nicholas I for arbitration. It eventually paid a lump sum of $\$ 1,204,960$ when a mixed commission deadlocked over individual awards. President John Quincy Adams then appointed a second American commission to award the money. See Fehrenbacher, Slaveholding Republic, pp. 91-98.

105.See H.R. Rep. No. $471,36^{\text {th }}$ Cong., $1^{\text {st }}$ Sess. (1860). A mixed commission, which was established in 1853 to settle all outstanding claims between the United States and Great Britain, cost the United States $\$ 24,535$ for its two commissioners and share of commission expenses. I was able to identify 13 of the 40 American claims as slavery-related. See Moore, International Arbitrations, I:415-19.

106.See James M. McPherson, Abraham Lincoln and the Second American Revolution (New York: Oxford University Press, 1991).

107.See Fehrenbacher, Slaveholding Republic, p. 241. 
108.See “Report on Fortifications at Dauphin Island,” February 9, 1825, American State Papers: Military Affairs II:831.

109.See Christopher L. Tomlins, “Nat Turner’s Shadow: Reflections on the Norfolk Dry Dock Affair of 1830-1831,” Labor History 33, no. 4 (Fall 1992): 494-518. I estimated these costs from the chart on page 516 of this article by averaging the number of slaves working on the project over the seven-year period from 1830-1836 at pay of \$.72 per day and 260 working days a year.

110.See Appropriation Ledgers, Vol. 11, Ledger 16 (July 1, 1854-June 30, 1859), p. 43.

111.See H.R. Ex. Doc. No. 34, 34 ${ }^{\text {th }}$ Cong., $3^{\text {rd }}$ Sess. (1857); H. Ex. Doc. No. $128,35^{\text {th }}$ Cong., $1^{\text {st }}$ Sess. (1858).

112.See Appropriation Ledgers, Vol. 11, Ledger 16 (July 1, 1854-June 30, 1859), p. 464.

113.See Carter, Territorial Papers, VI:299 (Mississippi/1812); VI:328-29 (Mississippi/1812); IX:139 (Louisiana/1803); IX:499-500 (Louisiana/1805); IX:559 (Louisiana/1806); IX:931 (Louisiana/1811); XXIII:63 (Florida/1826); XXIII:1066 (Florida/1828); XXIV:581 (Florida/1831); XXIV:643-44 (Florida/1832). The largest slave insurrection in United States history occurred in Orleans territory in January 1811. See James H. Dormon, “The Persistent Specter: Slave Rebellion in Territorial Louisiana,” Louisiana History 18, no. 4 (Fall 1977): 402.

114.See S. Ex. Doc. No. 82, $33^{\text {rd }}$ Cong., $1^{\text {st }}$ Sess. (1854); S. Ex. Doc. 158, $48^{\text {th }}$ Cong., $1^{\text {st }}$ Sess. (1884). Another $\$ 612,079$ was awarded in cases where claims for slave losses were combined with claims for other property losses. There was also an incursion in 1814 but the Treasury Department denied all claims for losses from that incursion. See Moore, International 
Arbitrations, I:4525. These incursions were at least partly motivated by conflicts with Seminoles over slaves. See Porter, Black Seminoles, pp. 8-11, 14-15, 19-24.

115.See Charles J. Kappler (ed.), Indian Affairs. Law and Treaties. (Washington: Government Printing Office, 1904), II:419. Chickasaws received an extra half section of land if they held 110 slaves; one extra section if they held more than 10 slaves.

116.See Calhoun Papers, XX:544-45 (1844).

117.See Merk, Slavery and Texas, p. 74 (n. 51). This type of federal expenditure might form a separate category: "slush" money spent by Southern presidents and cabinet members to support the continued existence of slavery.

118.See Tomlins, “Turner’s Shadow,” pp. 499-501, 503-05. An army major defended the cost overruns on a Florida military road built with slave labor on the grounds that the project still cost less than it would have cost using free labor. See Carter, Territorial Papers, XXIII:580 (Florida/1826).

119.In Slaveholding Republic, Fehrenbacher devoted separate chapters to the influence of slavery on American foreign policy and territorial policy.

120.Slavery was clearly not the only reason the federal government engaged in these activities. Yet, even when pursing purposes far removed from slavery, Congress attempted to maintain a sectional balance, as in making land grants to asylums for "deaf and dumb" children. See Walter I. Trattner, "The Federal Government and Social Welfare in Early Nineteenth-Century America,” in Compassion and Responsibility: Readings in the History of Social Welfare Policy in the 
United States, ed. Frank R. Breul and Steven J. Diner (Chicago: University of Chicago Press, 1980), pp. 161-64. 